\title{
ゴムとリング状の金具からなる排気管ハンガーの動的特性*
}

中原一成*1, 中川紀 壽*2, 大田勝敏*3

$$
\text { 三宅哲也光, Ramanjaneyulu KAKARLA*3 }
$$

\section{Dynamic Characteristics of Exhaust Hanger Composed of Rubber and Thin Metal Ring}

\author{
Kazunari NAKAHARA*3, Noritoshi NAKAGAWA, Katsutoshi OHTA, \\ Testuya MIYAKE and Ramanjaneyulu KAKARLA \\ ${ }^{* 3}$ Graduate School of Engineering, Hiroshima University, \\ 1-4-1 Kagamiyama, Higashi-hiroshima-shi, Hiroshima, 739-8527 Japan
}

\begin{abstract}
The dynamic characteristics of exhaust hangers for automotive use are studied for high frequencies at which the resonance vibration of the exhaust hangers occurs. A newly developed exhaust hanger composed of rubber and a thin metal ring is presented, which can provide a lower dynamic stiffness in a wide frequency range than an exhaust hanger made of solid rubber. A dynamic characterization testing and finite-element analysis of the exhaust hangers were carried out to clarify the frequency responses of dynamic stiffness in the high-frequency range. A method of treating the viscoelasticity of the rubber material using the finile-element method is proposed to predict the dynamic characteristics of the exhaust hangers. The finite-element method results show a good agreement with the experimental results for the frequency response of dynamic stiffness. Concerning the newly developed exhaust hanger, the effects of metal ring geometry and rubber hardness on the dynamic stiffness are examined to demonstrate the design principle for providing a low dynamic stiffness in a wide frequency range.
\end{abstract}

Key Words: Rubber, Dynamic Properties, Viscoelasticity Material, Finite Element Method, Exhaust Hanger

\section{1. 緒言}

自動車に用いられる排気管ハンガーは単に排気管を 保持するだけでなく，車両の振動騒音の低減に重要な 役割を担っている. 排気管ハンガーの動的特性は, 排 気系から車体に伝わる振動伝達力に大きな影響を及ぼ す.このことから，排気管ハンガーの動的特性に対し ては, アイドリング振動の低周波数領域 20-30 Hz か ら車内騒音で問題となる $500 \mathrm{~Hz}$ 付近までの高周波数 領域の間で良好な防振性能が求められる。

一般に，排気管ハンガーには図 1 に示されるソリッ ドゴムで形成されたものが使用されている(以下，こ のタイプの排気管ハンガーを「ソリッドラバーハンガ 一」と呼ぶ)。排気管を確実に保持するために，上部 と下部に円形の取付け穴が設けられており，これにサ ポートビンが挿入される。一つのサポートピンは車体

* 原稿受付 2006 年 12 月 20 日. 英文誌：JSME International Journal, Ser. C, Vol. 49, No. 3 (2006). pp. 750-757(原 稿受付 2006 年 2 月 28 日)

*1 正員, 広島大学大学院工学研究科(五 739-8527 東広島市鏡 山 1-4-1).

*2 正員, フェロー, 広島大学工学研究科.

*3 倉敷化工(株) (西 712-8555 倉敷市連島町矢柄四の町 4630)

E-mail : nakahara-k@kuraka.co.jp
側に取付けられており，もう一方のサポートピンは排 気管に取付けられている。このような排気管ハンガー を車両へ適用する際，振動騒音の目標性能を達成すべ く形状やゴム材質の面から最適の動的特性を追求する ことになる.しかしながら，排気管ハンガーの開発に おいては, $20 \mathrm{~Hz}$ から $500 \mathrm{~Hz}$ までの広い周波数領域 で良好な振動伝達特性を実現するのは困難であること が多い.この原因はゴム本体が弾性的に共振する周波 数で動的ばね定数にピークが現れるためである。この 周波数領域では動的ばね定数が大きくなるために振動 伝達力が高くなり，排気管支持系の車体に対する防振 性能が悪化する．排気管ハンガーについて，このよう な高い周波数領域における動的ばね定数の低減を扱っ た研究はほとんど見当たらない.

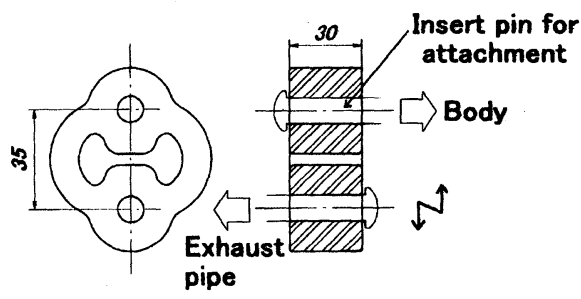

Fig. 1 Solid rubber hanger 
この問題を解決するために, 薄いばね鋼のリングに ゴムを接着した排気管ハンガーを開発した. 図 2 にそ の構造を示す. 取付け穴は, ソリッドラバーハンガー と同様にゴムで形成するとともに, 左右両側のリング 表面には薄いゴム層を接着している(以下,この排気 管ハンガーを「リングスプリングハンガー」と呼ぶ). 動的特性におけるリングスプリングハンガーの特長 は, 広範な周波数帯域でソリッドラバーハンガーより も低い動的ばね定数を実現できることにある。このた めに,ソリッドラバーハンガーに比べて, 共振周波数を 高くするとともに, リングの曲げ変形を利用すること でより低い動的ばね定数が得られるようにしている。

本研究の目的は, 薄いばね鋼のリングとゴムからな るリングスプリングハンガーの動的特性を加振実験と FEM 解析により明らかにすることである.まず，従 来の排気管ハンガーであるソリッドラバーハンガーに ついてその動的特性の課題を述べるとともに, リング スプリングハンガーを用いることでこの課題を大幅に 改善できることを示す.また, ゴム部の粘弾性効果を 取り入れた FEM 解析モデルをソリッドラバーハンガ 一およびリングスプリングハンガーに適用し, 動的ば ね定数のピークを生じさせる共振特性(共振モードと 共振周波数)を明らかにする. 本 FEM 解析モデルを 使って, 動的ばね定数に及ぼすリングの形状やゴム部 硬度の影響を調べ, できるだけ広い周波数領域にわた って低い動的ばね定数を実現するためのリングスプリ ングハンガーの設計指針を示す.

\section{2. 排気管ハンガーの動的特性}

$2 \cdot 1$ 動的特性の計測 排気管ハンガーの防振性 能を評価するための動的特性として, 動的ばね定数 $K$ (Dynamic stiffness)および損失角 $\delta$ (Loss angle)を用 いる. 排気管ハンガーが角振動数 $\omega$ で加振される場 合, 加振変位 $X(t)$ および伝達力 $F(t)$ は

$$
\begin{aligned}
& X(t)=X_{0} \sin (\omega t) \\
& F(t)=F_{0} \sin (\omega t+\delta)
\end{aligned}
$$

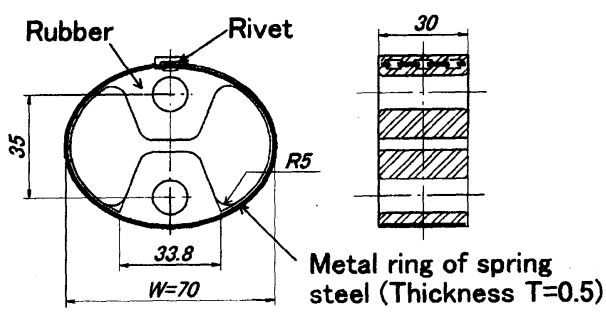

Fig. 2 Ring-spring hanger composed of thin metal ring and rubber
で表される，ここに， $X_{0}$ は加振の変位振幅， $F_{0}$ は伝 達力の振幅である. 動的ばね定数 $K$ は,

$$
K=F_{0} / X_{0}
$$

で定義される. 損失角 $\delta$ は, 加振変位 $X(t)$ に対する 伝達力 $F(t)$ の位相差として与えられる. 図 3 に動的 特性の試験装置の概要を示す. 取付け穴の一つを荷重 検出側に取付けられたピンに固定し，もう一方の取付 け穴にピンを通しそれを油圧加振テーブルに取付け る. 加振変位振幅 $X_{0}$ は油圧加振テーブル側の加速度 ピックアップで計測される振動加速度 $A(t)$ の振幅 $A_{0}$ から $X_{0}=A_{0} /\left(-\omega^{2}\right)$ として求める. 動的特性の計 測は, 振動加速度振幅 $\pm 29.4 \mathrm{~m} / \mathrm{s}^{2}$, 雾囲気温度 $23^{\circ} \mathrm{C}$ のもとで $50 \mathrm{~Hz}$ から $800 \mathrm{~Hz}$ まで加振周波数を上昇さ せて行う。

$2 \cdot 2$ ソリッドゴムで形成した排気管ハンガーの課 題 ゴム硬度の異なるソリッドラバーハンガーにつ いて測定した動的特性を図 4 に示す. 試験に用いたゴ 厶の硬度 $H_{s}(\mathrm{JIS} \mathrm{A})$ は $45^{\circ}, 55^{\circ}, 60^{\circ}$ である. 動的ば ね定数 $K$ は周波数とともに高くなるが, 動的ばね定 数にピークが現れる. ゴム硬度 $H s=45^{\circ}$ の場合, 432 $\mathrm{Hz}, 552 \mathrm{~Hz}$ の周波数で動的ばね定数 $K$ にピークが現 れ, 損失角 $\delta$ がマイナス側に大きく変化しているのが

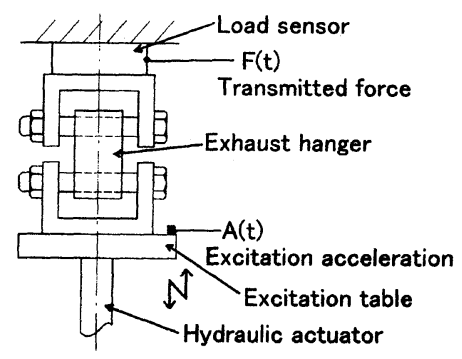

Fig. 3 Experimental test setup for measurement of dynamic characteristics

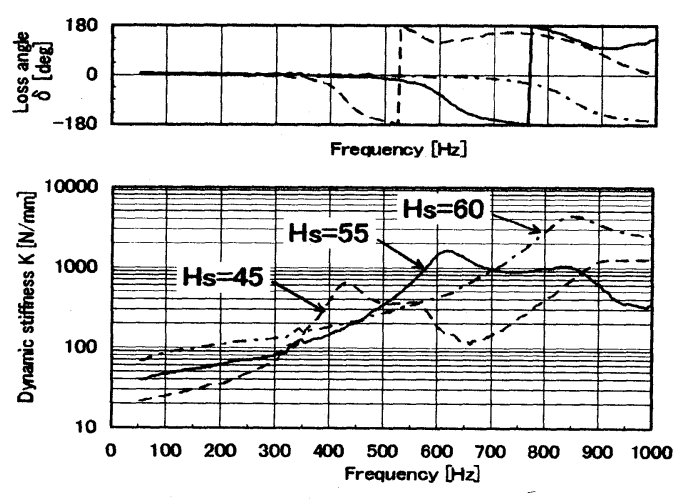

Fig. 4 Dynamic stiffness of solid rubber hangers 
わかる。このような動的ばね定数のピーク特性のため に，このピーク周波数を含む周波数帯域で振動伝達力 が大きくなり，この現象が排気管ハンガーの防振性能 を悪化させる、ゴム硬度を上げると, 動的ばね定数の ピークはそのピークレベルを上昇させながら高い周波 数領域へシフトしていく.ゴム硬度を $60^{\circ}$ まで高くす れば, 動ばね定数のピークを $852 \mathrm{~Hz}$ まで移動させる ことができる.この周波数は, 一般に車内騒音で問題 となる周波数帯域よりも高い.しかし, $350 \mathrm{~Hz}$ 以下 の周波数領域では, 動的ばね定数がゴム硬度 $45^{\circ}, 55^{\circ}$ の場合に比べて大きくなり，この周波数領域では防振 性能が悪化する.

$2 \cdot 3$ リングスプリングハンガーの動的特性 図 5 にリングスプリングハンガーの動的ば社定数の実測 結果を示す、ゴム硬度扔よびば齐鋼のリングの厚さ $T$, 長径寸法 $W$ は, それぞれ $H s=50^{\circ}, 0.5 \mathrm{~mm}, 70$ $\mathrm{mm}$ である. 比較のために, 図 4 に示したソリッドラ バーハンガー $\left(H s=45^{\circ}\right)$ の動的ばね定数を載せてい る.リングスプリングハンガーでは, ゴム硬度をソリ ッドラバーハンガーの硬度よりも高く設定して動的ば ね定数のピーク周波数をできるだけ高周波数側にシフ 卜させた。ソリッドラバーハンガーの場合, ゴム硬度 を上げると周波数全域で動的ばね定数が上昇する問題 があった。これに対してリングスプリングハンガーで はばね力の一部をばね鋼リングで担うことにより， ゴム硬度を上げてもソリッドラバーハンガーほど動的 ばね定数が上がらないようになった。したがって，リ ングスプリングハンガーでは, $250 \sim 550 \mathrm{~Hz}$ の広い周 波数領域においてソリッドラバーハンガーよりも低い 動的ばね定数を実現できていることがわかる，動的ば ね定数のピーク周波数は, $665 \mathrm{~Hz}$ にありソリッドラ バーハンガーの第一のピーク周波数に比べて $233 \mathrm{~Hz}$
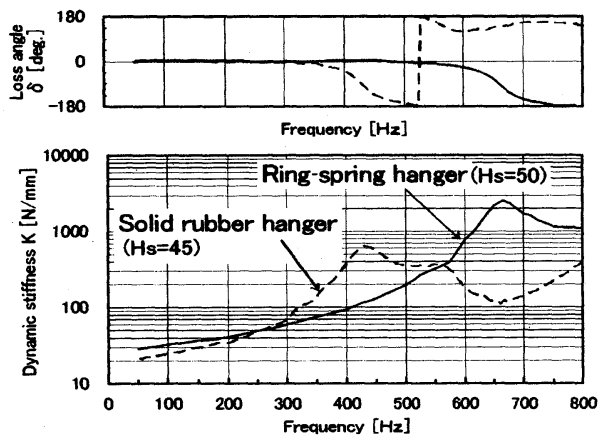

Fig. 5 Comparison of frequency dependence of dynamic stiffness between ring spring hanger and solid rubber hanger
高い.このピーク周波数は, 図 4 のソリッドラバーハ ンガー $\left(H s=55^{\circ}\right)$ における動的ばね定数の第一のピー ク周波数に近い. $250 \mathrm{~Hz}$ 以下の低周波数領域では, リングスプリングハンガーの動的ばね定数はソリッド ラバーハンガー $\left(H s=45^{\circ}\right)$ の值よりも少し高いが, 動 的ばね定数のピーク周波数が同程度のソリッドラバー ハンガー $\left(H s=55^{\circ}\right)$ に比べると低くなっている.

\section{3. 動的特性の FEM 解析}

3・1 FEM 解析モデル 排気管ハンガーの動的 特性を明らかにするためにゴムの粘弾性効果を考慮し た FEM 解析を行う。ソリッドラバーハンガーとリン グスプリングハンガーの FEM モデルを，それぞれ図 6(a)，（b)に示す．解析手順は，まず取付け穴 A(車 体側) の内面の変位を拘束し, 取付け穴 B (排気管側) に排気管を支持したときの引張たわみ $3 \mathrm{~mm}$ を静的 に与える. その変形状態のもとで, 取付け穴 B を微小 変位振幅の調和振動で上下方向に加振する. 動的特性 (動的ばね定数 $K$ と損失角 $\delta$ ) は, 取付け穴 B の加振 変位に対する取付け穴 $\mathrm{A} へ$ の伝達力の周波数応答と して計算する。このために，はん用解析コード Msc・ Marc の「粘弾性動的応答解析機能」(1) 使用した。 引張変形の静的解析においては, 幾何学非線形を取り 入れるとともにゴム部の材料構成則として超弾性モデ ルを採用した，要素モデルは，ゴム部を非圧縮性とし て 8 節点ソリッドの Herrmann 要素とし, リングス プリングハンガーにおけるばね鋼リングには薄肉シェ ル要素を用いた。ばね鋼リングのヤング率扔よびポア ソン比は，それぞれ $0.206 \mathrm{GPa}, 0.3$ とした。

$3 \cdot 2$ ゴムの粘弾性モデル 静的な引張変形の解 析に用いるゴムの超弾性モデルには，単位体積当たり のひずみエネルギー関数 $W$ を用いる。 $W$ として次 の Neo-Hook と呼ばれる形式(2) を採用した。

$$
W=C_{10}\left(\lambda_{1}^{2}+\lambda_{2}^{2}+\lambda_{3}^{2}-3\right)
$$

ここに $\lambda_{1}, \lambda_{2}, \lambda_{3}$ は変形の主軸方向の伸張率を表す。

$C_{10}$ はゴム材料の静的な弾性定数である.

ゴムの粘弾性については, 緩和せん断弾性率 $G(t)$ で表現する( ${ }^{(3)}$.

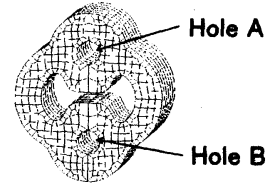

(a) Solid rubber hanger

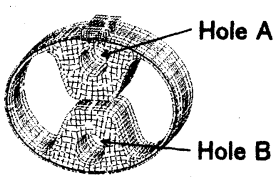

(b) Ring-spring hanger
Fig. 6 Finite-element analysis model 


$$
G(t)=G^{\infty}(1+2 g(t))
$$

$G(t)$ は単位ステップ入力のせん断ひずみに対する緩 和応力である。 $G^{\infty}$ は静的なせん断弾性率であり, $G^{\infty}$ $=2 C_{10}$ となる. $g(t)$ は, 粘弾性による緩和せん断弾性 率の時間依存性を表し, $2 G^{\infty} g(t)$ が粘弾性による緩和 せん断弾性率となる.ゴムが角振動数 $\omega$ で調和振動 のせん断ひずみを受ける場合, せん断応力 $\sigma(t)$ は, 複 素せん断弾性率 $G^{*}(\omega)$ を用いて次のように表される。

$$
\sigma(t)=G^{*} \varepsilon(t)
$$

ここに, $\varepsilon(t)=\varepsilon_{0} \exp (-j \omega t)$ であり, $G^{*}$ は $g(t)$ を用 いて以下のように導かれる。

$$
\begin{aligned}
& G^{*}(\omega)=G^{\infty}\left(1+2 g^{*}(\omega)\right) \cdots \\
& g^{*}(\omega)=j \omega \int_{0}^{\infty} g(t) e^{-j \omega t} \mathrm{~d} t
\end{aligned}
$$

一方, $G^{*}(\omega)$ はゴムの貯蔵せん断弾性率 $G_{r}$, ロス ファクタ $\eta$ を用いて次式で表される.

$$
G^{*}(\omega)=G_{r}(1+j \eta(\omega))
$$

式( 7$)$, (9)から, $g^{*}(\omega)$ の実部 $g_{r}$ および虚部 $g_{i}$ は $G_{r}, \eta, G^{\infty}$ を使って次式で与えられる.

$$
\begin{aligned}
& g_{r}=\frac{1}{2}\left(G_{r} / G^{\infty}-1\right) \\
& g_{i}=G_{r} \eta /\left(2 G^{\infty}\right) \cdots \cdots
\end{aligned}
$$

動的特性の FEM 解析では, $G^{\infty}, g_{r}, g_{i}$ を用いて粘 弾性の周波数応答解析を行う. $G^{\infty}$ および $G^{*}(\omega)$ に ついては, ゴム材のテストピースを用いた静的および 動的特性試験により計測した。解析に必要な $g_{r} お よ$ び $g_{i}$ は, $G^{\infty}, G_{r}, \eta$ の実測値を式 $(10),(11) に$ 代入す ることにより求めた.

$G^{\infty}, G_{r}, \eta$ の計測のために, 円柱形のテストピース を用いた単純せん断方向の静的ばね定数試験および動 的ばね定数試験を行った。図 7 に, 並列配置したテス トピース 2 個とジグからなる供試体を示す.テストピ 一スは, 両端に剛体プレートを接着した円柱形ゴムで あり, 円柱形ゴムの直径 $d$ および高さ $h$ はそれぞれ $\phi 25 \mathrm{~mm}, 25 \mathrm{~mm}$ である. $G^{\infty}$ は, 次式により求めら れる。

$$
G^{\infty}=\frac{4 h}{\pi d^{2}}\left(1+\frac{4 h^{2}}{9 d^{2}}\right) K_{s}
$$

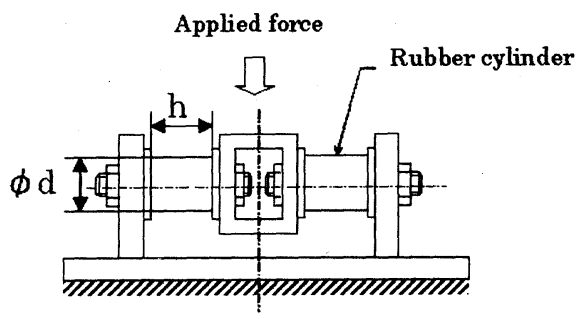

Fig. 7 Test assembly for determination of $G^{\infty}, G_{r}$ and $\eta$
ここに, $K_{s}$ は円柱形ゴムについて実測される静的な せん断ばね定数を表す。式(12)は曲げ変形を考慮した 円柱形ゴムの単純せん断方向のばね定数計算式から導 出した(4). 動的ばね定数試験には非共振法(4)を適用 し, 貯蔵せん断弾性率 $G_{r}$ およびロスファクタ $\eta$ を測 定した。 $G_{r}$ は, 次式から求めた。

$$
G_{r}=\frac{4 h}{\pi d^{2}}\left(1+\frac{4 h^{2}}{9 d^{2}}\right) K_{d}
$$

ここで, $K_{d}$ は円柱形ゴムについて実測された貯蔵せ ん断ばね定数である. 式(13) は式(12)において $K_{s}$ を $K_{d}$ に置換えたものである.

図 8 に, ゴム硬度の異なる 3 種類のゴム材質の夕イ プ A, B, Cについて行った $G_{r}, \eta$ の計測結果を示す. ゴム材質 $\mathrm{A}, \mathrm{B}, \mathrm{C}$ のゴム硬度 $H_{s}(\mathrm{JIS} \mathrm{A})$ は, それぞ れ $45^{\circ}, 50^{\circ}, 58^{\circ}$ である. 本研究では, カーボンブラッ クで補強されたEPDM(Ethylene propylene dienemonomer) ゴムを使用した。動的ばね定数試験 のための加振は, 加振振幅土 $0.1 \mathrm{~mm}$, 雾囲気温度 $23^{\circ} \mathrm{C}$ で $5120 \mathrm{~Hz}$ を掃引した. $120 \mathrm{~Hz}$ を超える周波 数領域では, 測定される $K_{d}$ および $\eta$ がテストピース の固定ジグの共振の影響を受けるためゴム材料の $G_{r}$ およびクを正確に測定することができなかった。こ のため動的ばね定数試験は $120 \mathrm{~Hz}$ までの周波数範囲 で行った. 図 8 によると $G_{r}$ は周波数とともに単調に 増加し, その増加傾向はゴム硬度が高いほど顕著であ ることがわかる。一方, $\eta$ は加振周波数とともにわず かに増加する傾向にあるが, その周波数依存性は $G_{r}$ に比べて小さい. また，ゴム硬度が高くなると $G_{r}$ お よびクは大きくなる.

動的特性の解析では $800 \mathrm{~Hz}$ までの周波数領域を対 象にするため, この周波数領域までの $G_{r}$ および $\eta の$ 值が必要である. 解析に使用する $120 \mathrm{~Hz}$ から 800 $\mathrm{Hz}$ までの $G_{r}$ は，図 8 の実測值を基に外挿した值を 使うことにした. 図 8 に示されるように $G_{r}$ が周波数 $f$ の対数值とほほ直線関係にあることから， $G_{r}$ と周 波数 $f$ の関係は次式で表されると仮定した.

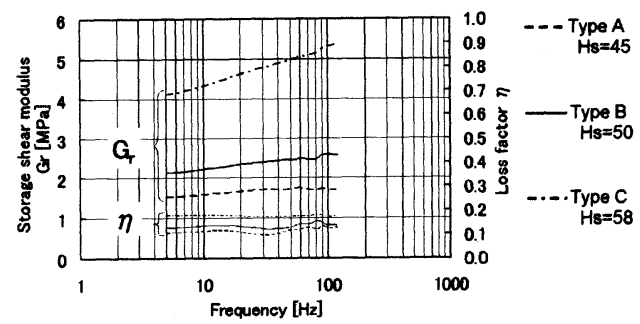

Fig. 8 Dynamic properties as functions of excitation frequency for different values of rubber hardness 
$G_{r}=a \log _{10} f+b$

ここに $a, b$ は, $10 \mathrm{~Hz}$ と $100 \mathrm{~Hz}$ での $G_{r}$ の值を用い て 3 種類のゴム材質ごとに決まる定数である. 解析に 用いるクについては周波数にかかわらず一定值とし， $10 \mathrm{~Hz}$ での実測值を採用した。表 1 に, 解析に用いた $G^{\infty}$, 周波数 $10 \mathrm{~Hz}$ および $100 \mathrm{~Hz}$ での $G_{r}, \eta$, 定数 $a$, $b$ について, これらの值をまとめて示す.

$3 \cdot 3$ 解析結果と実測結果の比較 ソリッドラバ ーハンガーおよびリングスプリングハンガーについ て, 動的特性の解析值と実測値を比較し本解析モデル の検証を行った．図 9 に,ソリッドラバーハンガーの 動的特性について解析値と実測値を比較した結果を示 す.解析値と比較した実測値は図 4 におけるゴム硬度 $H s=45^{\circ}$ の動的特性であり, このゴム材質は表 1 の夕 イプ A に相当する.動的ばね定数 $K$ の解析結果は実 測の周波数特性をよく表している.また，損失角 $\delta$ は, 実測結果と同様に動的ばね定数のピーク周波数に おいてマイナス側に大きく変化していることがわか る.ただし，動的ばね定数の二つのピーク周波数につ いては, 解析結果が実測結果より $17 \mathrm{~Hz}$ 低周波数側に ある。これは， $G_{r}$ を外挿した高周波数領域において， 式(14)で与えられる $G_{r}$ が実際のゴム材料の值よりも 低くなっているためと考えられる.また，Kのピーク レベルの解析結果は実測結果より少し低くでており, これは解析に用いたロスファクタクの值が実際の値 よりも高めに設定されたためと考えられる.図 10 に,

Table 1 Static and dynamic properties of rubber

\begin{tabular}{|c|c|c|c|c|c|c|c|}
\hline \multirow[t]{2}{*}{ Rubber type } & \multirow{2}{*}{\begin{tabular}{|l|} 
Hardness \\
Hs (JIS A) \\
\end{tabular}} & \multirow{2}{*}{$\begin{array}{c}\mathrm{G}_{\infty} \\
{[\mathrm{MPa}]}\end{array}$} & \multicolumn{2}{|c|}{$\left.\mathrm{G}_{\mathrm{r}} \mathrm{Mpa}\right]$} & \multirow{2}{*}{$\begin{array}{c}\eta \\
\text { at } 10 \text { th } \\
\end{array}$} & \multirow{2}{*}{$\begin{array}{c}\mathrm{a} \\
{[\mathrm{MPa}]}\end{array}$} & \multirow{2}{*}{$\begin{array}{c}\mathrm{b} \\
{[\mathrm{MPa}]} \\
\end{array}$} \\
\hline & & & $10+k$ & $100 \mathrm{~Hz}$ & & & \\
\hline A & $45^{\circ}$ & 0.809 & 1.60 & 1.73 & 0.11 & 0.132 & 1.47 \\
\hline B & $50^{\circ}$ & 0.964 & 222 & 2.58 & 0.13 & 0.356 & 1.87 \\
\hline C & $58^{\circ}$ & 1.35 & 4.35 & 5.33 & 0.18 & 0.973 & 3.38 \\
\hline
\end{tabular}
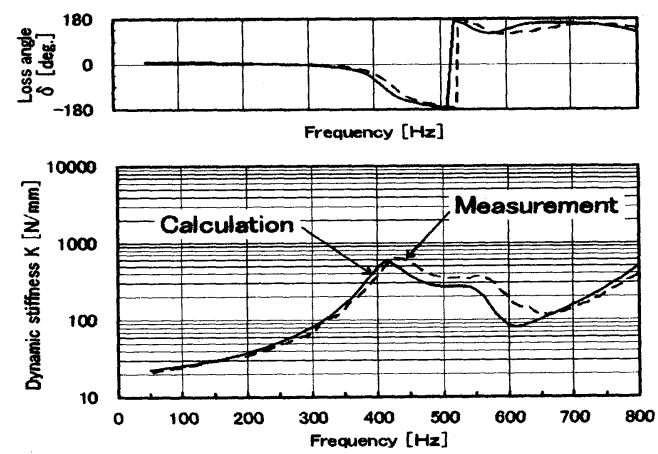

Fig. 9 Comparison of calculated and measured dynamic characteristics of solid rubber hanger $\left(H s=45^{\circ}\right)$
リングスプリングハンガーについて動的特性の解析值 と実測値の比較結果を示す.ゴム硬度は $H s=50^{\circ}$ で あり，ゴム材質はタイプ Bである．解析による動的ば ね定数 $K$ および損失角 $\delta$ は実測値とよく一致してい る.この場合も，Kのピークレベルにおいて解析結果 が実測よりも低くなっており，解析に使用した クが実 際の值よりも大きいことを示している.

以上の解析結果と実測結果の比較により，ゴムの粘 弾性を取り入れた本解析モデルは排気管ハンガーの動 的特性の解析に適用できることが示された。

$3 \cdot 4$ 排気管ハンガーの共振現象の解明 解析モ デルを用いて動的ばね定数のピーク周波数における排 気管ハンガーの振動モードを調べた。図 9 に示された ソリッドラバーハンガーの動的特性について，その動 的ばね定数がピークになる二つの周波数(解析值)での 振動モードを図 11 (a)，（b ）に示す．図中の矢印は加 振変位の方向を示している. 第一のピーク $425 \mathrm{~Hz}$ で はハンガーラバー両側のラバー部が上下に振動し, 加 振変位とほほ同じ位相で動いている。第二のピーク $530 \mathrm{~Hz}$ では, 両側のラバー部が水平方向に振動し, 上 方の加振変位で内側に変位し下方の加振変位で外側に 伸びている.一方, 動的ばね定数にピークの生じない 周波数 $50 \mathrm{~Hz}$ での振動モードを図 11 ( c ) に示す.こ の振動モードは静的な引張・圧縮変形と同じである. 動的ばね定数がピークを持つ周波数での振動モードは その周波数に特有の振動であることがわかる. 一方, 図 10 のリングスプリングハンガーの動的特性につい て, 動ばね定数のピーク周波数 (解析値)における振動 モードを図 12 に示す.この場合，ピーク周波数は一 つのみであるが，その周波数での振動モードは，ソリ ッドラバーハンガーにおいて第一のピーク周波数で現 れる振動モードと同じである。両側のばね鋼リング部
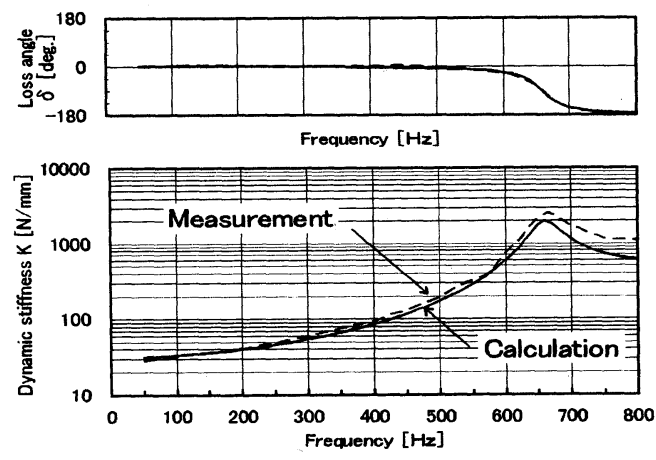

Fig. 10 Comparison of calculated and measured dynamic characteristics of ring-spring hanger $\left(H s=50^{\circ}\right)$ 
が加振変位とほほ同位相で振動しており, 図 11（a）の 振動モードに対応することがわかる.

\section{4. 動的特性に及ぼす 設計パラメータの影響}

ここでは, 提案した解析モデルを用いて, リングス プリングハンガーの動的特性に及ぼす設計パラメータ の影響を明らかにし，得た動的ばね定数低減のための 設計指針を示す、設計パラメータとしては，ゴムの硬 度のほか, 図 2 に示されるばね鋼リングの厚さ $T$ お よび長径寸法 $W$ とした. 設計パラメータは, 図 5 で 比較に用いたリングスプリングハンガーの諸元(ゴム 硬度 $H s=45^{\circ}, T=0.5 \mathrm{~mm}, W=70 \mathrm{~mm}$ ) 基準にし て実用上の設計可能な範囲で変更した。また，解析に 用いる FEM モデルは，図 2 に示される形状に対して ゴムのフィレット部 R 5 (4 箇所)を除去した形状とし た.フィレット $\mathrm{R}$ 部があると, 長径寸法 $W$ を小さく するにつれて,フィレット $\mathrm{R}$ 部がリングの曲げ変形に 与える影響の度合いが大きくなる。このためフィレッ
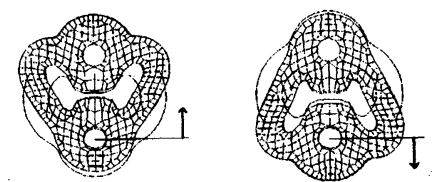

(a) $425 \mathrm{~Hz}$
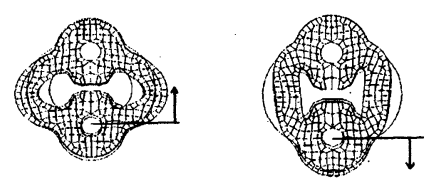

(b) $530 \mathrm{~Hz}$
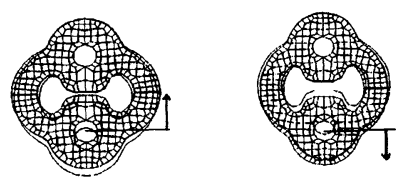

(c) $50 \mathrm{~Hz}$

Fig. 11 Vibration modes of solid rubber hanger under excitation for different frequencies
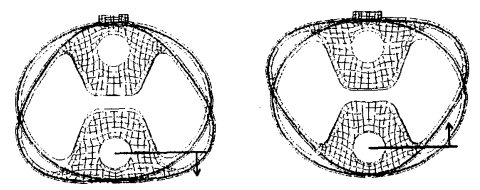

Fig. 12 Vibration mode of ring spring hanger at excitation frequency of $660 \mathrm{~Hz}$
ト $\mathrm{R}$ 部のない形状で解析を行った.

まずゴム硬度の影響について調べる。図 13 に, ゴ 厶硬度を $H_{S}=45^{\circ}, 50^{\circ}, 58^{\circ}$ と上げた場合の動的ばね 定数を示す. 解析に用いたゴム材質は, 表 1 のタイプ A，B，Cである．ゴム硬度を上げると，動的ばね定数 $K$ のピークは, ピークレベルをほとんど変えずに高周 波数側へ移ることがわかる. なお， $300 \mathrm{~Hz}$ 以下の周 波数領域では動的ばね定数は大きくなるが，その増加 幅は図 4 に示したソリッドラバーハンガーの場合に比 べて小さい.これは，ばね鋼のリングがばね力の一部 を担っているため, ゴム硬度を高くしてもその影響が ソリッドラバーハンガーのようには顕著に現れないた めである、したがって，ゴム硬度を高く設定すること により, $300 \mathrm{~Hz}$ 以下の周波数領域における動的ばね 定数の上昇を抑えながら動的ばね定数のピーク周波数 を高周波数側にシフトさせることができる。

次にばね鋼リングの厚さ $T$ を $0.3 \mathrm{~mm}, 0.4 \mathrm{~mm}$, $0.5 \mathrm{~mm}, 0.6 \mathrm{~mm}$ と厚くした場合の動的ばね定数を 図 14 に示す. 厚さ $T$ を大きくしていくと動的ばね定 数のピーク周波数が高周波数側にシフトするが， 400 $\mathrm{Hz}$ 以下の周波数領域の動的ばね定数が上昇する.ま たばね鋼リングの短径を一定にして長径寸法 $W$ を 小さくすると, 動的ばね定数は厚さ $T$ を大きくする

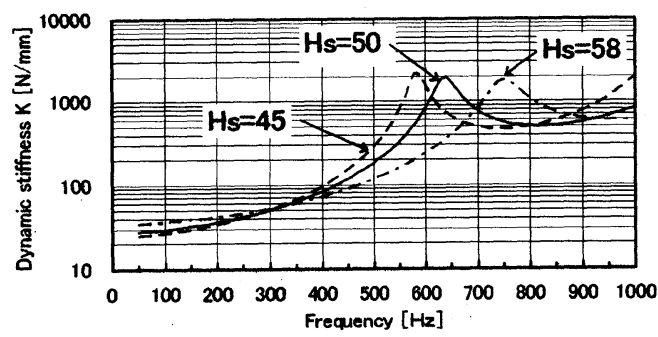

Fig. 13 Dynamic stiffness of ring-spring hanger as function of frequency for rubber hardness $H_{s}=$ $45,50,58$

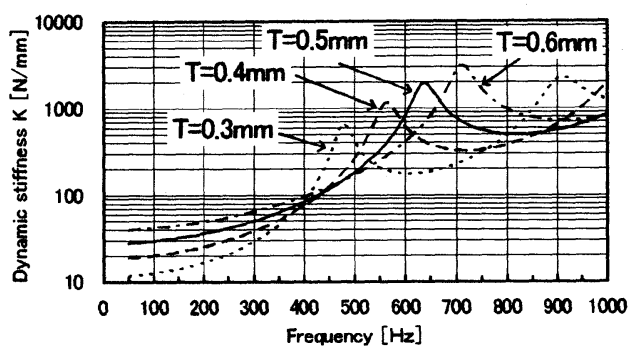

Fig. 14 Dynamic stiffness of ring-spring hanger as function of frequency for $T=0.3 \mathrm{~mm}, 0.4 \mathrm{~mm}$, 0.5 and $0.6 \mathrm{~mm}$ 


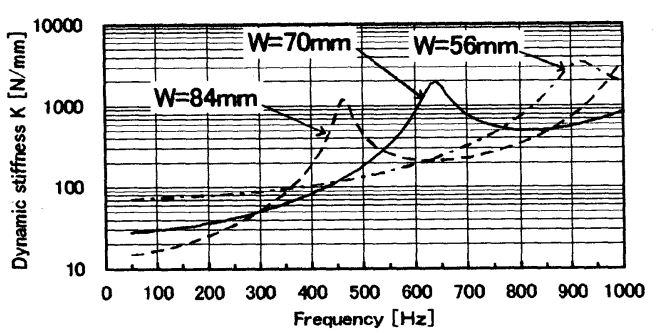

Fig. 15 Dynamic stiffness of ring-spring hanger as function of frequency for $W=56 \mathrm{~mm}, 70 \mathrm{~mm}$ and $84 \mathrm{~mm}$

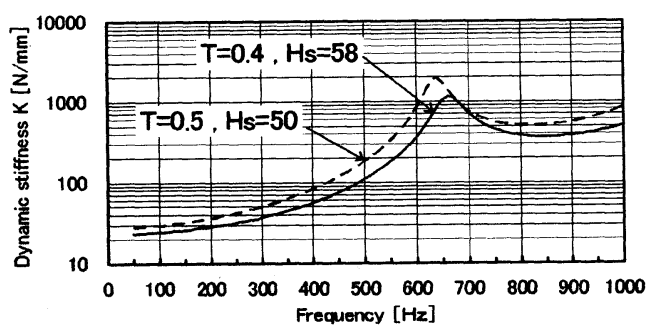

Fig. 16 Dynamic stiffness as function of frequency for different combinations of thickness $T$ and rubber hardness $H s: T=0.4 \mathrm{~mm}$ and $H s=58 ; T$ $=0.5$ and $H_{s}=50$ (ring-spring hanger, $W=70$ $\mathrm{mm}$ )

場合と同様の変化を示す. 図 15 には, $W$ を基準値 70 $\mathrm{mm}$ に対して $84 \mathrm{~mm}(+20 \%), 56 \mathrm{~mm}(-20 \%)$ とし た場合の動的ばね定数を示す.Wが小さくなると, 動的ばね定数のピーク周波数は高くなり $350 \mathrm{~Hz}$ 以下 の周波数領域で動的ばね定数が上昇する.

以上の設計パラメータの影響を調べた解析結果を基 にして, 基準の諸元における動的ばね定数よりもさら に低い動的ばね定数を実現するための検討を行った. 図 14,15 に示されるように, ばね鋼リングの寸法 $W$ を広げるか, または厚さ $T$ を薄くすれば, $300 \mathrm{~Hz}$ 以 下の周波数領域での動的ばね定数を低減できる。ま た,これに伴って動的ばね定数ピークの周波数は低周 波数側に移ってくる.このとき動的ばね定数のピーク レベルは, ピーク周波数が $500 \mathrm{~Hz}$ 以下に下がってく ると, 厚さ $T$ を薄くするほうが $W$ を大きくする場合 に比べ低い值を示すことがわかる，そこで, 基準の諸 元に対して, 厚さを $0.1 \mathrm{~mm}$ 薄くして $T=0.4 \mathrm{~mm}$ と し, ゴム硬度を $H s=58^{\circ}$ まで高くした場合の解析を行 った.これは，ばね鋼リングの厚さ $T$ を薄くするこ とにより低周波数領域の動的ばね定数を下げるととも に,ゴム硬度を高くすることにより動的ばね定数のピ ーク周波数を高周波数側にシフトさせることを狙った
ものである，その解析結果を図 16 に示す。 $W$ は 70 $\mathrm{mm}$ とした. 基準の諸元である厚さ $T=0.5$, ゴム硬 度 $H s=50^{\circ}$ の場合に対して，周波数域全体で動的ばね 定数を低減できていることがわかる。このように，リ ングスプリングハンガーにおいては, 厚さ $T$ を薄く しゴム硬度を高くすることにより動的ばね定数を広い 周波数領域において低減できる.

\section{5. 結言}

薄いばね鋼のリングとゴムからなるリングスプリン グハンガーの動的特性を, 従来のソリッドラバーハン ガーの動的特性と比較して動的特性試験と FEM 解析 により明らかにした。

（1）動的ばね定数試験により，ソリッドラバーハ ンガーは $300 \mathrm{~Hz}$ 以上の高周波数領域においてゴムの 共振により動的ばね定数にピークを生じることがわか った。これに対してリングスプリングハンガーでは, 動的ばね定数のピーク周波数が $600 \mathrm{~Hz}$ を超えており， 広い周波数領域においてソリッドラバーハンガーより も低い動的ばね定数を実現できることを示した。

（2）ゴム部の粘弾性効果を取り入れた FEM 解析 のモデル化手法により, $50 \mathrm{~Hz}$ から $800 \mathrm{~Hz}$ までの周 波数領域における排気管ハンガーの動的特性解析が可 能であることを示した。

（3）本解析モデルをソリッドラバーハンガーおよ びリングスプリングハンガーに適用し, 動的ばね定数 のピークを生じさせる共振モードを明らかにした。

（4） FEM 解析モデルを使って, リングスプリン グハンガーの動的特性に及ぼす設計パラメータ(ゴム 硬度，ばね鋼リングの幅および厚さ)の影響を明らか にし，低い動的ばね定数を実現するための設計指針を 示した.

\section{文献}

(1) Morman, K. N. and Nagtegaal, J. C., Finite Element Analysis of Sinusoidal Small-amplitude Vibrations in Deformed Viscoelastic Solids. Part 1: Theoretical Development, International Journal for Numerical Methods in Engineering, Vol. 19 (1983), pp. 1079-1103.

(2) Iizuka, H. and Yamashita, Y., Identification of StressStrain Data of Rubber for Finite Element Analysis, Nippon Gomu Kyoukaishi (in Japanese), Vol. 77, No. 9 (2004), pp. 306-311.

(3) MARC Analysis Research Corporation-Europe, The Determination of Phi-Functions in A Non-Linear Pre-Stressed Rubber Component Subjected to Harmonic Vibrations, MTR-9310, (1993).

(4) Boushingomu Kenkyukai ed., Boushingomu (in Japanese), (1998), p. 88, Nippon Tetsudosharyou Kogyokai. 